Article

\title{
Parental Involvement as a Protective Factor in School Adjustment among Retained and Promoted Secondary Students
}

\author{
Cristina Serna ${ }^{1, *(1)}$ and Isabel Martínez ${ }^{2}$ (1) \\ 1 Departament of Psychology, University of Castilla-La Mancha, Camino Nohales 4, 16071 Cuenca, Spain \\ 2 Departament of Psychology, University of Castilla-La Mancha, Avda de los Alfares 44, 16071 Cuenca, Spain; \\ MIsabel.Martinez@uclm.es \\ * Correspondence: cristina.serna@uclm.es
}

Received: 8 November 2019; Accepted: 8 December 2019; Published: 11 December 2019

check for updates

\begin{abstract}
This study analyzes the relationship of parental involvement and school adjustment among secondary students considering their school integration, school satisfaction, and prosocial disposition. The analysis also considers academic performance through the grade retention. Study sample was 1043 Spanish adolescents aged between 12 and 17 years (51.5\% girls, $M=14.21, S D=1.38)$. A factorial ( $3 \times 2 \times 2 \times 2)$ multivariate analysis of variance (MANOVA) was applied for the outcome variables of school integration, school satisfaction, and prosocial behavior, with parental educational involvement, grade retention, sex, and age as independent variables. The results show that both parental involvement and academic performance are positively related to school adjustment. In addition, parental involvement influences adolescents' school adjustment, regardless of academic performance, being a protective factor in that adjustment.
\end{abstract}

Keywords: school adjustment; parental involvement; academic performance; prosocial behavior; school integration; school satisfaction; adolescence

\section{Introduction}

The experiences associated with the academic environment are a significant determinant in adolescent's development and well-being [1,2]. School adjustment, therefore, is a fundamental aspect during this period. It is a multifactorial construct that involves attitudinal, behavioral, cognitive, and social aspects related to the student's relationship with the school environment and the ability to adapt to it $[3,4]$. School adjustment is manifested in the degree to which a student feels committed to the school, accepted by the other school members, and satisfied [5,6]. A good school adjustment is related to positive behaviors, academic results, and social relations, and this can be noted in the opposite trend in students with school maladjustment $[7,8]$.

School adjustment includes academic factors (such as academic performance); social factors, related to social adjustment (such as school integration) and behavioral adjustment (such as social competence and prosocial behavior); family factors (such as parental involvement in children's school adaptation); and school satisfaction factors [9-11].

\subsection{Parental Educational Involvement}

The family is an essential institution in the students' school experience. Numerous studies highlight family variables as essential determinants of academic process. The majority of family variables, both structural (socioeconomic and educational level of parents, cultural resources, family structure) and dynamic (parent-child relationship, affective climate, disciplinary style, parental level 
of cognition), exert their effects on academic performance through the level of parental involvement or support in education [12-14]. This implication refers to parental behavior as concerns their attention and participation, at home and at school, aimed at helping children in their school learning experiences $[15,16]$.

Parental involvement in school is related, directly or indirectly, to academic performance $[17,18]$. These effects seem to be mediated by the perception that children have of such involvement, relating positively to their school adjustment $[9,19]$. For example, improvement in academic performance has been observed through improved academic motivation, school satisfaction, school commitment, self-esteem, social competence, prosocial behavior, normative adjustment, and, likewise, through a reduction in absenteeism and antisocial behaviors [20,21]. However, studies point to the existence of gender differences in terms of the assessments that the adolescent makes regarding the educational practices exercised by both parents, with a tendency to perceive the mother's educational practices more positively than those of the father's [14,22], with girls being the ones who indicate the biggest differences in this perception $[23,24]$. Although parental involvement has been related to school adjustment in different studies, it has not been proven to be equally effective for adolescents with good and poor academic performance.

\subsection{Academic Performance}

Several authors recognize a close connection between the adolescent's evolutionary aspect and academic decline, especially determined by the decrease in motivation and school commitment $[25,26]$. This process is attributed to the rapid transformation in their psychosocial and cognitive development and to the changes in some predictive variables of school achievement, such as factors related to family, social relationships, self-concept, motivation, attributional style, attitude toward studying, and learning strategies $[27,28]$, as well as the difficulties of adapting to the secondary school social and educational context $[29,30]$.

School failure is present in the educational systems of all developed countries [31-33]. This has been revealed by various international comparative studies conducted by the International Association for the Evaluation of Educational Achievement (IEA) and by the triple UOE organization the United Nations Educational, Scientific and Cultural Organization (UNESCO), the Organization for Economic Cooperation and Development (OECD), and the Statistical Office of the European Communities (EUROSTAT). Early school dropout is an international constant, with an average in the European Union of $10.6 \%$ of young people who leave education and training early. However, a heterogeneous distribution between countries has been observed. The proportion of early leavers in 2018 showed the best results in countries such as Croatia (3.3\%), Slovenia (4.2\%), and Switzerland (4.4\%), and the worst in countries such as Romania (16.4\%), Malta (17.5\%), and Spain (17.9\%) [31]. As part of the Europe 2020 strategy, a benchmark was adopted that should be reached by 2020, namely that the proportion of early leavers in the European Union should not exceed 10\%, but some countries are far from this goal, especially Spain, which has the highest percentage of early school leaving. The absenteeism rate is also considerable, taking into account that it is a variable associated with low academic performance, being the average absenteeism in the OECD of 33\% and in the European Union of $25 \%$.

The results of the Third International Mathematics and Science Study (TIMSS) Survey, conducted by the IEA in 2015, show that certain countries with a high economic level have a lower performance than expected in Mathematics and Science, in contrast with other countries with a lower level of development. Thus, in mathematics and science, countries such as France (489 and 487 points) or Spain (505 and 518 points) obtain a lower average compared to the 525 and 528 points of the OECD, respectively; and smaller than that of other countries with a lower development index, such as Russia, with 564 and 567 points, respectively. In general, Spain is one of the developed countries with the highest rate of school failure and early school leaving.

A factor that has been assigned a predictive value in academic performance is the student's academic development. There is wide evidence that places previous performance as a determinant of 
current performance, both directly and indirectly, through the effect of other intermediate variables such as expectations or motivation [34]. Within the history of academic achievement, grade retention has been considered both an indicator and a predisposing factor of school failure, considering it is closely associated with school dropout and represents a high percentage of students who fail academically [35]. Compared to the promoted students, the retained students show a lower academic performance, a lower probability of graduation, a greater probability of dropping out, a greater tendency to occupy employment positions of lower formative and occupational status, as well as a negative socioemotional impact, a poorer personal adjustment, and lower self-concept [36,37]. Therefore, not only does grade retention not achieve the intended compensatory benefits, but it also predisposes the student to repeat and, finally, drop out of the educational system, which constitutes a risk factor for social exclusion $[38,39]$. Some researchers consider that the cause resides in the ability of previous performance to condition the beliefs and expectations of students about their future chances of success or failure, as well as the expectations and attitudes of teachers and parents [34,40,41].

\subsection{Social Adjustment—School Integration}

Social adjustment is a fundamental aspect for adapting to school environment and is manifested in the degree to which a student feels integrated, that is, accepted, respected, supported, and encouraged to participate by other school members. School integration is closely related to the subjective sense of school belonging. The sense of belonging has a positive impact on motivation, commitment, expectations of achievement, self-concept, self-efficacy, satisfaction, teacher-student relationships, and academic performance [42,43]. Alienation, which implies losing the sense of belonging and distancing oneself in social relationships, is connected with several negative consequences, such as anti-normative behaviors, criminal and violent acts, negative academic performance, and school dropout [44,45].

An important part of social adjustment is the relationships of students with teachers and peers. The teacher-student relationship has been associated with different school adjustment determinants $[11,46]$. A negative interaction between teachers and students encourages a negative self-image and feelings of incompetence in the student, a negative attitude toward school and authority, negative perception and rejection of peers, increased likelihood of antisocial behavior, and worsening academic performance $[47,48]$. As the quality and closeness in this relationship increases, the students improve their academic and global self-concept, self-esteem, perceived self-efficacy, commitment, academic achievement, and positive perception and peers' acceptance [49,50]. Moreover, the relationship with peers determines the level of school integration, this being a fundamental factor for school adjustment. Thus, peer rejection has been linked to school failure and maladjustment, manifested through at-risk and antisocial behaviors. Adolescents who feel accepted by their peers have higher levels of motivation, school commitment, and academic performance, in addition to a greater psychosocial adjustment $[48,51]$.

\subsection{School Satisfaction-Student's Subjective Well-Being}

Another dimension usually related to school adjustment is school satisfaction, representing one of the domains of life satisfaction that shape the general subjective well-being of a person [52-54]. It is defined as the subjective assessment of the quality of school life or as the concordance between the value that the student gives to different aspects of the educational context and the perception they have about it, and is related to indicators such as school adaptation, commitment, participation, and motivation [55,56]. During adolescence, school environment satisfaction is a decisive variable for student's adjustment; it improves their academic performance, their engagement, motivation, self-esteem, and their relationships with teachers and classmates and decreases the probability of disruptive behaviors. In contrast, there is an increased probability of misconduct and school failure when a student feels dissatisfied $[7,57]$. 


\subsection{Behavioral Adjustment-Prosocial Behavior}

Behavioral adjustment is another dimension of school adjustment, as has been proven in the relationship between deviant behavior from the social norm and school maladjustment, both within $[58,59]$ and out of school $[60,61]$. Within the school environment, the indicators of coexistence and social adjustment related to behavioral adjustment are especially relevant. In this sense, aggressive students tend to have low school adjustment, being more rejected by classmates and teachers and showing less school commitment and higher rates of school failure [62-64]. On the opposite side, prosocial students tend to adjust well to school. Prosocial behavior is defined as voluntary behavior aimed at benefiting others and is characterized by a concern for the rights, feelings, welfare, and interests of others in coherence with self-transcendence values $[65,66]$. This behavior exerts an inhibitory effect on antisocial and maladaptive behaviors and has a driving effect on social competence, contributing to the establishment of positive interpersonal relationships [67-69]. It has also shown a positive relationship with academic performance; it improves sociometric status, in that prosocial students are more accepted by their peers; it favors self-concept and academic self-efficacy and the use of various learning and studying strategies; and it is related to academic motivation and well-being and personal satisfaction [70-72]. In addition, some evidence points to significant differences in adolescent prosocial behavior based on gender, with higher levels of prosocial behaviors among women than among men $[67,72]$. There are discrepancies in differences by age and, while some authors find a decrease in prosocial behavior as age increases [73], others do not observe differences between adolescents aged 13 and 17 [74]. Some studies show an increase in dispositional empathy with age, but only in girls-it stays constant in boys [75].

\subsection{Sex, Age, and School Adjustment}

In general, studies indicate a more unfavorable trend among male students in most indicators of school adjustment [76-78], such as retentions, qualifications, premature dropout, age appropriateness, commitment, academic expectations, expectations, and self-efficacy. Other differences related to social life have also been found, with better scores of girls in social competence, prosocial behavior, school belonging, and more positive relationships with teachers and peers [79].

Age is another prominent factor-several studies confirm that as students get older, school adjustment and academic performance decrease, increasing the risk of dropping out of school and decreasing age appropriateness per grade. Moreover, satisfaction and subjective well-being seem to be declining as age increases $[80,81]$. However, the evidence is not clear regarding some specific indicators of school adjustment, like school integration and prosocial behavior, and some studies either offer inconclusive results or find no significant differences [21].

\subsection{The Present Study}

This study analyzes the relationship of parental educational involvement with school adjustment in secondary school students, taking into account the academic performance of adolescents. The indicators of school adjustment used were school integration, school satisfaction and prosocial behavior. Academic performance was measured through the retention or promotion of the students. Two demographic control variables (sex and age) traditionally used in school adjustment studies were also taken into account. In this study, we considered the following questions:

1. Are there differences in school adjustment according to the degree of retention, that is, the degree of retention affects school adjustment variables such as school integration, school satisfaction, and prosocial behavior? We expected to find significant differences depending on grade retention, with retained adolescents showing worse scores than their promoted peers in all school adjustment indicators observed. 
2. Is parental support related to school adjustment measures, regardless of the academic functioning of adolescents (retained vs promoted)? We expected students who received more parental support to have higher levels of prosocial behavior, school integration, and school satisfaction, regardless of their academic performance.

\section{Materials and Methods}

\subsection{Participants and Procedure}

The participants in the study were 1043 Spanish students who attended secondary education. A random selection of 15 public schools was conducted from the complete list of secondary schools in middle-class neighborhoods from five cities of the same region in the center of Spain, with around $\pm 3 \%$ sampling error (confidence level: 95\%). According to Kalton [82], when groups (i.e., educational centers) are selected randomly, the elements that make up those groups (i.e., students) will be similar to what a random system would provide. One group was assessed for each educational level, a total of four student groups per secondary school-283 first-year students (27.1\%), 298 second-year students (28.6\%), 220 third-year students (21.1\%), and 242 fourth-year students (23.2\%). Slightly over half of the students were girls $(51.5 \%)$, and 506 were boys $(48.5 \%)$, with an age range of $12-17$ years old $(\mathrm{M}=14.21$; $\mathrm{SD}=1.38$ ). All the questionnaires were completed anonymously following Institutional Review Board approval during tutoring sessions. The Ethics Committee at the University of University of Castilla-La Mancha, where the research was designed, granted ethical approval for the study.

\subsection{Measures and Instruments}

Parental involvement was measured by an adapted version of the Family Involvement Questionnaire Elementary (FIQ-E) of Manz, Fantuzzo, and Power [83] for secondary students, validated in Serna, 2012 [13]. It consists of 43 items whose responses are made on a four-point Likert-type scale that ranges from 1 ("rarely") to 4 ("always"). This questionnaire evaluates parental involvement behaviors in three scenarios of their children's academic life in activities from the educational center (i.e., "your parents participate in the organization of your school's activities"), in promoting a positive learning environment at home (i.e., "your parents support your studies with other activities at home"), and in communication between parents and educational staff about the progress of their children (i.e., "your parents talk to the teacher about the work you should do at home"). The sample adequacy was satisfactory with a Kaiser-Meyer-Olkin (KMO) index of 0.97, achieving a significant Barlett sphericity test $(p<0.0001)$. The alpha value was 0.95 . Different researches have contrasted the psychometric adequacy of the FIQ and have confirmed its validity among populations of diverse socioeconomic and cultural backgrounds [84-86]. In the present study, parental involvement was defined by trichotomizing the sample with a tertile split, categorizing into three groups of involvement-low (scores below tertile 33), medium (scores over tertile 33 and below tertile 66), and high (scores over tertile 66).

Psychological Sense of School Membership Scale (PSSM) [42] was used to measure school integration. This scale has 18 items regarding the feeling of belonging or alienation in the educational environment. Responses are made on a five-point Likert-type scale that ranges from 1 ("strongly disagree") to 5 ("strongly agree"). In accordance with previous studies on the structure of the PSSM [87,88], two factors were found through an exploratory factor analysis by the extraction of principal components with varimax rotation: a first factor called belonging-acceptance, configured by 13 items that refer to the degree to which the adolescents feel they belong to the school and feel accepted within it (i.e., "feel like an important part of this school"), and a second factor, called rejection, which groups five items on the degree of rejection and alienation that the students feel inside their school (i.e., "it is difficult for people like me to be accepted here"). All items have factorial weights greater than 0.40 in their corresponding factor. The total variance explained by the factors was $39.609 \%$ (factor 1: $23.710 \%$; factor 2: $15.899 \%$ ). The alpha value was 0.83 for the global scale, 0.84 for the belonging-acceptance subscale and 0.73 for the rejection subscale. The sample shows adequacy for the 
application of the scale, with a Kaiser-Meyer-Olkin (KMO) index of 0.88 and a statistically significant Barlett sphericity test $(p<0.0001)$. This scale has been used in studies on the sense of belonging in diverse ethnic and cultural groups, students of different educational levels, with academic and behavioral problems, learning difficulties, disabilities or in bullying contexts [43,89-91].

To measure the satisfaction that students feel with the academic environment, subscale of satisfaction with the school from the Huebner's [56] Multidimensional Students' Life Satisfaction Scale (MSLSS) was applied. This consists of eight items that ask the students about their satisfaction with respect to general aspects of their educational center. Responses are made on a four-point Likert-type scale that ranges from 1 ("never") to 4 ("always"). The sample showed suitability for its application. The Kaiser-Meyer-Olkin (KMO) index was 0.82, and the Barlett sphericity test was statistically significant $(p<0.0001)$. The factorial analysis of the items indicated saturation in two factors: the first, called school satisfaction, was formed by five items (i.e., "I am looking forward to school"); the second grouped three items that referred to school dissatisfaction (i.e., "there are many things I don't like about school"). All items show factorial weights greater than 0.50 in the assigned factor. The total variance explained by both factors was $54.867 \%$ (factor $1: 33.287 \%$; factor 2 : $21.581 \%$ ). The alpha value was 0.77 for the global scale, 0.78 for the satisfaction factor and 0.59 for the dissatisfaction factor. This instrument has been validated among adolescents of various Primary and secondary education levels [92-94], as well as among students of various nationalities $[95,96]$.

Prosocial behavior in students was measured through the subscale of prosocial behavior from the Teenage Inventory of Social Skills (TISS) of Inderbitzen and Foster [97], using its adapted Spanish version [75]. It has 20 items that assess the social competence of adolescents in relationships with their peers (i.e., "I help other boys or girls with their homework when they ask me for help"). Responses are made on a six-point Likert-type scale that ranges from 1 ("it does not describe me at all") to 6 ("it fully describes me"). The sample showed suitability for its application, with a value of 0.93 on the Kaiser-Meyer-Olkin index (KMO) and a statistically significant Barlett sphericity test $(p<0.0001)$. The alpha value of the scale was 0.91 .

\subsection{Data Analysis}

A factorial ( $3 \times 2 \times 2 \times 2)$ multivariate analysis of variance (MANOVA) was applied for the outcome variables: school integration (belonging/acceptance and rejection), school satisfaction (satisfaction and dissatisfaction), and prosocial behavior, with parental educational involvement (low, medium and high), sex (boys vs. girls), age (12-14 vs. 15-17 year-olds) and grade retention (retained vs. promoted) as independent variables. Univariate F follow-up tests were conducted within the multivariate significant overall differences, and significant results on the univariate tests were followed with Bonferroni's comparisons between all possible pairs of means. All analyses were carried out using the SPSS 24.0 statistical program.

\section{Results}

\subsection{Educational Parental Involvement and School Adjustment}

The distribution of the parental involvement groups according to sex, age, and grade retention among the students is represented in Table 1. As expected, the MANOVA showed a significant main effect for parental involvement, $\Lambda=0.923, F(10,2030.0)=8.282, p<0.001$ (see Table 2). Univariate analysis (Table 3 ) indicated statistically significant differences in belonging-acceptance, $F(2,1040)=17.417, p<0.001$, rejection, $F(2,1040)=4.487, p<0.05$, satisfaction, $F(2,1040)=23.819$, $p<0.001$ and prosocial behavior $F(2,1040)=22.457, p<0.001$, depending on parental involvement. Bonferroni tests $(\alpha=0.05)$ showed that students who perceived medium $(\mathrm{M}=3.39, \mathrm{DT}=0.65)$ and high parental involvement $(\mathrm{M}=3.49, \mathrm{DT}=0.68)$ had a greater sense of belonging to the school than those who perceived a low parental involvement $(\mathrm{M}=3.19$, DT $=0.62)$. Likewise, students who perceived low parental involvement $(\mathrm{M}=2.21, \mathrm{DT}=0.94)$ felt more rejection in school than those of 
the high parental involvement group $(\mathrm{M}=2.02, \mathrm{DT}=0.74)$. Regarding school satisfaction, differences were observed between the three groups of adolescents who felt a low, medium and high parental involvement, progressively showing greater satisfaction with the school as parental support increased $(\mathrm{M}=2.16, \mathrm{DT}=0.52, \mathrm{M}=2.32, \mathrm{DT}=0.65$, and $\mathrm{M}=2.49, \mathrm{DT}=0.68$, respectively). Finally, differences in prosocial behavior were also found between the three groups of parental involvement (low, medium and high), so that the prosocial behavior increased as the level of parental support received by the student did $(\mathrm{M}=4.09, \mathrm{DT}=0.89, \mathrm{M}=4.26, \mathrm{DT}=0.87$, and $\mathrm{M}=4.52, \mathrm{DT}=0.83$, respectively). In general, the data show that adolescents who perceive their parents as being more involved in their educational trajectory obtain more positive scores in school adjustment measures, than those who perceive them as less involved.

Table 1. Parental involvement groups distributed by sex, age, and grade retention.

\begin{tabular}{ccccc}
\hline & & \multicolumn{3}{c}{ Parental Involvement } \\
\hline & & Low & Medium & High \\
\hline \multirow{2}{*}{ Total } & $\mathrm{N}=1043$ & $329(31.5)$ & Frequency (\%) \\
\hline \multirow{2}{*}{ Sex } & Boys $(\mathrm{N}=506)$ & $158(31.2)$ & $159(31.4)$ & $363(34.8)$ \\
& Girls $(\mathrm{N}=536)$ & $171(31.9)$ & $192(35.8)$ & $179(37.3)$ \\
\multirow{2}{*}{ Age } & $12-14(\mathrm{~N}=624)$ & $162(25.9)$ & $197(31.6)$ & $265(42.5)$ \\
& $15-17(\mathrm{~N}=419)$ & $167(39.8)$ & $154(36.7)$ & $98(23.4)$ \\
\hline \multirow{2}{*}{ Grade Retention } & Retained $(\mathrm{N}=755)$ & $227(30.1)$ & $257(34.1)$ & $271(35.9)$ \\
& Promoted $(\mathrm{N}=288)$ & $102(35.4)$ & $94(32.6)$ & $92(31.9)$ \\
\hline
\end{tabular}

Table 2. Factorial MANOVA $\left(3^{\mathrm{a}} \times 2^{\mathrm{b}} \times 2^{\mathrm{c}} \times 2^{\mathrm{d}}\right)$ for school integration, school satisfaction, and prosocial behavior.

\begin{tabular}{ccccc}
\hline Source of Variation & $\boldsymbol{\Lambda}$ & $\boldsymbol{F}$ & $\mathbf{g l}_{\text {between }}$ & gl $_{\text {error }}$ \\
\hline (A) Parental involvement $^{\mathrm{a}}$ & 0.92 & $8.28^{* * *}$ & 10 & 2030.00 \\
(B) Sex $^{\text {b }}$ & 0.90 & $22.35^{* * * *}$ & 5 & 1015.00 \\
(C) Age & 0.98 & $2.76^{* * *}$ & 5 & 1015.00 \\
(D) Retention & 0.95 & $10.48^{* * *}$ & 5 & 1015.00 \\
A $\times$ B & 0.99 & 0.86 & 10 & 2030.00 \\
A $\times$ C & 0.99 & 0.48 & 10 & 2030.00 \\
A $\times$ D & 0.98 & 1.33 & 10 & 2030.00 \\
B $\times$ C & 0.99 & 0.53 & 5 & 1015.00 \\
B $\times$ D & 0.99 & 1.86 & 5 & 1015.00 \\
C $\times$ D & 0.99 & 0.68 & 5 & 1015.00 \\
A $\times$ B $\times$ C & 0.99 & 0.64 & 10 & 2030.00 \\
A $\times$ B $\times$ D & 0.99 & 0.97 & 10 & 2030.00 \\
A $\times$ C $\times$ D & 0.99 & 0.94 & 10 & 2030.00 \\
A $\times$ B $\times$ C $\times$ D & 0.99 & 0.95 & 10 & 2030.00
\end{tabular}

Note: a1, low, a2, medium, a3, high; b1, boy, b2, girl; c1, 12-14 years old, c2, 15-17 years old; d1, retained, d2, promoted; $* * p<0.05, * * * p<0.001$. 
Table 3. Means, standard deviations (in brackets), F values, type I error probabilities, and post hoc Bonferroni ${ }^{\mathrm{a}}$ tests between parental involvement and school adjustment (school integration, school satisfaction, and prosocial behavior).

\begin{tabular}{|c|c|c|c|c|}
\hline Parental Involvement & & & & \\
\hline Source of Variation & Low Support & Medium Support & High Support & $F(2,1040)$ \\
\hline \multicolumn{5}{|c|}{ School integration } \\
\hline Belonging/acceptance & $3.19(0.62)^{2}$ & $3.39(0.65)^{1}$ & $3.49(0.68)^{1}$ & $17.417^{* * *}$ \\
\hline Rejection & $2.21(0.94)^{1}$ & $2.11(0.78)$ & $2.02(0.74)^{2}$ & $4.487^{* *}$ \\
\hline \multicolumn{5}{|c|}{ School Satisfaction } \\
\hline Satisfaction & $2.16(0.52)^{3}$ & $2.32(0.65)^{2}$ & $2.49(0.68)^{1}$ & $23.819 * * *$ \\
\hline Dissatisfaction & $2.24(0.65)$ & $2.20(0.68)$ & $2.19(0.70)$ & 0.591 \\
\hline \multicolumn{5}{|c|}{ Prosocial disposition } \\
\hline Prosocial behavior & $4.09(0.89)^{3}$ & $4.26(0.87)^{2}$ & $4.52(0.83)^{1}$ & $22.457^{* * *}$ \\
\hline
\end{tabular}

Note: Bonferroni test $\alpha=0.05 ; 1>2>3 . * * p<0.05, * * * p<0.001$.

\subsection{Academic Performance (Grade Retention) and School Adjustment}

As was hypothesized, the MANOVA showed a significant main effect for academic performance measured through the grade retention, $\Lambda=0.951, F(5,1015.0)=10.485, p<0.001$ (Table 2). Univariate analysis (Table 4 ) indicated statistically significant differences between retained and promoted students in belonging/acceptance, $F(1,1041)=17.447, p<0.001$, rejection, $F(1,1041)=44.234, p<0.001$, satisfaction, $F(1,1041)=15.954, p<0.001$ and prosocial behavior $F(1,1041)=16.880, p<0.001$. Promoted students had higher scores than their retained peers in belonging/acceptance $(\mathrm{M}=3.42, \mathrm{DT}=0.65$, vs. $\mathrm{M}=3.22$, $\mathrm{DT}=0.68)$, satisfaction $(\mathrm{M}=2.38, \mathrm{DT}=0.62$, vs. $\mathrm{M}=2.20, \mathrm{DT}=0.67)$ and prosocial behavior $(\mathrm{M}=4.37$, $\mathrm{DT}=0.82$, vs. $\mathrm{M}=4.12$, $\mathrm{DT}=0.99$ ). In addition, retained students scored higher in rejection than those who had been promoted $(\mathrm{M}=2.39, \mathrm{DT}=0.83$, vs. $\mathrm{M}=2.01, \mathrm{DT}=0.81)$. The results indicate, therefore, that grade retention is related to more negative scores in the means of school adjustment than grade promotion.

\subsection{Sex, Age and School Adjustment}

Although not central to the focus of this study, we analyzed main effects for sex, $\Lambda=0.901$, $F(5,1015.0)=22,352, \mathrm{p}=0.000$, and age, $\Lambda=0.987, F(5,1015.0)=2763, \mathrm{p}=0.017$ (Table 2). Univariate analysis for sex (Table 4) indicated significant differences in belonging/acceptance, $F(1,1041)=12.076$, $p<0.05$, rejection, $F(1,1041)=28.561, p<0.001$, satisfaction, $F(1,1041)=34.735, p<0.001$, dissatisfaction, $F(1,1041)=37.422, p<0.001$, and prosocial behavior, $F(1,1041)=106.780, p<0.001$. Girls showed higher scores than boys in belonging/acceptance $(\mathrm{M}=3.43$, $\mathrm{DT}=0.65$, vs. $\mathrm{M}=3.29, \mathrm{DT}=0.68)$, satisfaction, $(\mathrm{M}=2.44, \mathrm{DT}=0.61$, vs. $\mathrm{M}=2.21, \mathrm{DT}=0.65)$, and prosocial behavior $(\mathrm{M}=4.56, \mathrm{DT}=0.76$, vs. $\mathrm{M}=4.02, \mathrm{DT}=0.91)$. However, boys scored higher in rejection $(\mathrm{M}=2.26, \mathrm{DT}=0.82$, vs. $\mathrm{M}=1.99$, $\mathrm{DT}=0.82)$ and dissatisfaction $(\mathrm{M}=2.34, \mathrm{DT}=0.71$, vs. $\mathrm{M}=2.091, \mathrm{DT}=0.62)$. In general, the data indicate better scores among girls than among boys in all school adjustment measures. Additionally, statistically significant differences were observed between the age groups in school satisfaction, the youngest adolescents (12-14 years old) being more satisfied than the adolescents in the 15-17-year-old group $(\mathrm{M}=2.39, \mathrm{DT}=0.66$, vs. $\mathrm{M}=2.24, \mathrm{DT}=0.59)$. 
Table 4. Means, standard deviations (in brackets), $F$ values, and type I error probabilities between grade repetition, sex, age, and school adjustment (school integration, school satisfaction, and prosocial behavior).

\begin{tabular}{|c|c|c|c|c|c|c|c|c|c|}
\hline \multirow{2}{*}{ Source of Variation } & \multicolumn{3}{|c|}{ Grade Retention } & \multicolumn{3}{|c|}{ Sex } & \multicolumn{3}{|c|}{ Age } \\
\hline & $\begin{array}{l}\text { Retained } \\
\text { Students }\end{array}$ & $\begin{array}{l}\text { Promoted } \\
\text { Students }\end{array}$ & $F(1,1041)$ & Boys & Girls & $F(1,1041)$ & $12-14$ & $15-17$ & $F(1,1041)$ \\
\hline \multicolumn{10}{|c|}{ School integration } \\
\hline Belonging/acceptance & $3.42(0.65)$ & $3.22(0.68)$ & $17.447^{* * *}$ & $3.29(0.68)$ & $3.43(0.65)$ & $12.076^{* *}$ & $3.38(0.68)$ & $3.35(0.65)$ & 0.493 \\
\hline Rejection & $2.01(0.81)$ & $2.39(0.83)$ & $44.234^{* * *}$ & $2.26(0.82)$ & $1.99(0.82)$ & $28.561 * * *$ & $2.11(0.83)$ & $2.13(0.84)$ & 0.109 \\
\hline \multicolumn{10}{|c|}{ School satisfaction } \\
\hline Satisfaction & $2.38(0.62)$ & $2.20(0.67)$ & $15.954 * * *$ & $2.21(0.65)$ & $2.44(0.61)$ & $34.735 * * *$ & $2.39(0.66)$ & $2.24(0.59)$ & $12.531 * * *$ \\
\hline Dissatisfaction & $2.20(0.66)$ & $2.24(0.73)$ & 0.740 & $2.34(0.71)$ & $2.09(0.62)$ & $37.422^{* * *}$ & $2.20(0.68)$ & $2.23(0.67)$ & 0.538 \\
\hline \multicolumn{10}{|c|}{ Prosocial disposition } \\
\hline Prosocial behavior & $4.37(0.82)$ & $4.12(0.99)$ & $16.880^{* * *}$ & $4.02(0.91)$ & $4.56(0.76)$ & $106.780^{* * *}$ & $4.28(0.88)$ & $4.32(0.88)$ & 0.373 \\
\hline
\end{tabular}




\section{Discussion}

Overall, the results confirm the hypothesis of this research: parental involvement improves adolescent's school adjustment regardless of their academic performance (retention vs promotion of the students). Parental involvement and good academic performance are shown as protective factors of adolescents' school adjustment. Students who receive greater educational support from their parents show better school adjustment than those who perceive less of a parental involvement, with a greater sense of school belonging, higher school satisfaction and prosocial disposition. Therefore, parental involvement acts as a protective factor for adolescents' school adjustment, relating positively to school adjustment and negatively to school maladjustment. These results are consistent among the different groups of students, regardless of their academic performance (retained or promoted), sex, and age, with no significant interaction effects.

These results are consistent with other studies that relate educational parental involvement to different indicators of school adjustment $[9,19]$. Thus, the influence of parental support on school integration has been verified $[48,98,99]$. The evidence also shows that parental involvement influences children's social competence and prosocial orientation, improving social relationships and normative adjustment, and reducing antisocial behaviors [21,24,100]. Finally, the association of family relationships and satisfaction has been proven, with more satisfied adolescents when the affective climate, involvement, support, communication, and cohesion in the family are greater [52,101-103]. In fact, parental involvement has been related with to a wide variety of variables that reflect adolescent adjustment, including self-esteem, social values, substance use, or academic achievement [104,105].

In respect to academic performance, this study also confirms that being promoted in school can act as a protective factor of adolescent school adjustment. Taking grade retention as an indicator of previous performance, differences between retained and promoted students are observed, with those that have not been retained feeling most accepted and satisfied in school and presenting a greater prosocial tendency. That is, the academic performance maintains a positive relationship with school adjustment and a negative relationship with the school maladjustment. These results are consistent among the different groups of students regardless of parental involvement, sex, and age, without interaction effects between independent variables. The data found in the present study are consistent with those of previous studies that associate academic performance with different dimensions of school adjustment. On the one hand, there is some empirical evidence regarding the relationship between school integration and student academic performance $[47,106]$. Students with a greater sense of school belonging have better scores on variables that are positively related to academic performance [42,43], while several negative consequences of school alienation have been verified, leading to diminished academic performance $[45,107,108]$. On the other hand, as in previous studies, we have confirmed the positive relationship between academic performance and prosocial behavior [109-111]. Regarding school satisfaction, the results of this study are consistent with those of other authors who confirm their relationship with academic performance [52,101,112].

Regarding the demographic control variables included in the analyses (sex and age), differences according to sex in the school setting are confirmed, with girls scoring higher in all considered measures. Girls are more accepted, show more prosocial behaviors, and feel more satisfied in school, experiencing less rejection and dissatisfaction than boys. Some previous research has confirmed similar results. Thus, it has been shown that girls have a greater sense of belonging to school, greater social competence, and more probability of being accepted, while boys are more likely to be socially excluded $[30,76,104]$. Other studies have also verified that female school satisfaction is significantly higher than male's [113,114]. In addition, some evidence points to significant differences in adolescent prosocial behavior based on gender, with higher levels of prosocial behaviors among girls than among boys [67,72]. In any case, the common trend indicates more unfavorable rate among boys in most school adjustment indicators [76-79].

Finally, age is only related in this study with satisfaction as an indicator of school adjustment, the younger group of adolescents being more satisfied with school. Likewise, other studies have 
confirmed an inverse relationship of satisfaction with age, with an evolutionary decrease in subjective well-being during adolescence and higher levels of school satisfaction among younger students [115,116]. Regarding the rest of the school adjustment variables, although research suggests that it decreases in adolescence as age increases [81], some studies either offer inconclusive results regarding school integration according to age or find no significant differences $[77,80]$, the same as with prosocial behavior [21].

The results of this study confirm and extend previous research on school adjustment. Data of the study show that parental involvement can act as a protective factor of school adjustment (school integration, school satisfaction, prosocial behavior) among students with good academic performance (promoted students) and those with poor academic performance (retaining students). In addition, this work contributes to broadening knowledge about the role of prosocial behavior in school adjustment, given that research on this subject is scarce, especially in the Spanish context, where there are hardly any studies on prosocial behavior in secondary education. However, the study also has limitations. On the one hand, the limitations derived from a correlational and cross-sectional study prevent causal statements. Therefore, in the absence of longitudinal or experimental evidence, the findings should be considered as preliminary. On the other hand, the use of self-report measures always leads to possible associated biases.

Further research is required that adds more variables in the analysis related to school adjustment and deepening the effect of parental support on retained students. The results derived from this study raise some educational implications that should be considered. It is necessary to take into account the family context into the educational process. The prevention of school maladjustment should include work with families, raise awareness about the relevance of parental support, and promote positive relationships between parents and children.

Author Contributions: Conceptualization, C.S. and I.M.; methodology, C.S. and I.M.; data curation, C.S.; formal analysis, C.S.; writing-original draft preparation, C.S.; writing-review and editing, C.S. and I.M.; supervision, C.S. and I.M.

Funding: This research received no external funding.

Conflicts of Interest: The authors declare no conflict of interest.

\section{References}

1. Gilman, R.; Huebner, E.S. A review of life satisfaction research with children and adolescents. Sch. Psychol. Q. 2003, 18, 192-205. [CrossRef]

2. Gutiérrez, M.; Gonçalves, T.O. Activos para el desarrollo, ajuste escolar y bienestar subjetivo de los adolescentes. Int. J. Psychol. Psychol. Ther. 2013, 13, 339-355.

3. Harrison, B.K.; Clarcke, L.; Ungerer, J.A. Children's Drawings Provide a New Perspective on Teacher-Child Relationship Quality and School Adjustment. Early Child. Res. Q. 2007, 22, 55-71. [CrossRef]

4. Rodríguez-Fernández, A.; Ramos-Díaz, E.; Madariaga, J.M.; Arribillaga, A.; Galende, N. Steps in the construction and verification of an explanatory model of psychosocial adjustment. Eur. J. Educ. Psychol. 2016, 9, 20-28. [CrossRef]

5. Azpiazu, L.; Esnaola, I.; Ros, I. Factores contextuales y variables individuales en el ajuste escolar. Int. J. Dev. Educ. Psychol. 2014, 6, 327-336. [CrossRef]

6. Luckner, A.E.; Pianta, R.C. Teacher-student interactions in fifth grade classrooms: Relations with children's peer behavior. J. Appl. Dev. Psychol. 2011, 32, 257-266. [CrossRef]

7. Baker, J.A.; Maupin, A.N. School satisfaction and children's positive school adjustment. In Handbook of Positive Psychology in the Schools; Gilman, R., Huebner, E.S., Furlong, M.J., Eds.; Routledge: New York, NY, USA, 2009; pp. 189-196.

8. Martínez, I.; Murgui, S.; García, O.F.; García, F. Parenting in the digital era: Protective and risk parenting styles for traditional bullying and cyberbullying victimization. Comput. Hum. Behav. 2019, 90, 84-92. [CrossRef] 
9. Aminabadi, Z.; Khodapanahi, M.K.; Dehghani, M. Examining the mediating role of cognitive emotion regulation in the relationship between perceived parenting style dimensions and academic achievement. J. Behav. Sci. 2011, 5, 109-117.

10. García, F.; Serra, E.; García, O.F.; Martinez, I.; Cruise, E. A third emerging stage for the current digital society? Optimal parenting styles in Spain, the United States, Germany, and Brazil. Int. J. Environ. Res. Public Health 2019, 16, 2333. [CrossRef]

11. Nikkel, L.E. Goodness of Fit between Teacher and Child Characteristics: Implications for Teachers' Perceptions of Children's School Adjustment; Simon Fraser University: Vancouver, BC, Canada, 2010.

12. Georgiou, S.N.; Tourva, A. Parental attributions and parental involvement. Soc. Psychol. Educ. 2007, 10, 473-482. [CrossRef]

13. Serna, C. Factores Psicosociales en el Riesgo de Fracaso Escolar: El Contexto Social en el Rendimiento Académico. Ph.D. Thesis, Universidad de Castilla-La Mancha, Albacete, Spain, 2012.

14. Serna, C.; Martínez, I.; Jiménez, L. Efecto de la implicación parental en el riesgo de fracaso escolar desde la percepción del estudiante de secundaria. In Proceedings of the 6th International Congress of Educational Sciences and Development, Setúbal, Portugal, 21-23 June 2018.

15. Bronfenbrenner, U. Ecology of the family as a context for human development: Research perspectives. Dev. Psychol. 1986, 22, 723-742. [CrossRef]

16. Epstein, J.L. School/family/community partnerships: Caring for the children we share. Phi Delta Kappan 1995, 76, 701-712. [CrossRef]

17. Jeynes, W.H. A meta-analysis: The relationship between parental involvement and African American school outcomes. J. Black Stud. 2016, 47, 195-216. [CrossRef]

18. Scheerens, J. Educational effectiveness and ineffectiveness. A Critical Review of the Knowledge Base; Springer: Dordrecht, The Netherlands, 2016. [CrossRef]

19. Kiuru, N.; Nurmi, J.E.; Aunola, K.; Salmela-Aro, K. Peer group homogeneity in adolescents' school adjustment varies according to peer group type and gender. Int. J. Behav. Dev. 2009, 33, 65-76. [CrossRef]

20. Mounts, N.S.; Valentiner, D.P.; Anderson, K.L.; Boswell, M.K. Shyness, sociability and parental support for the college transition: Relation to adolescent's adjustment. J. Youth Adolesc. 2006, 35, 71-80. [CrossRef]

21. Sánchez-Queija, I.; Oliva, A.; Parra, A. Empatía y conducta prosocial durante la adolescencia. Rev. Psicol. Soc. 2006, 21, 259-271. [CrossRef]

22. Phares, V.; Fields, S.; Kamboukos, D. Fathers' and mothers' involvement with their adolescents. J. Child Fam. Stud. 2009, 18, 1-9. [CrossRef]

23. García, M.C.; Cerezo, M.T.; de la Torre, M.J.; Carpio, M.V.; Casanova, P.F. Prácticas educativas paternas y problemas internalizantes y externalizantes en adolescentes españoles. Psicothema 2011, 23, 654-659.

24. Torrente, G.; Vazsonyi, A.T. The salience of the family in antisocial and delinquent behavior among spanish adolescents. J. Genet. Psychol. 2008, 169, 187-197. [CrossRef]

25. Peetsma, T.; Hascher, T.; van der Veen, I.; Roede, E. Relations between adolescents' self-evaluations, time perspectives, motivation for school and their achievement in different countries and at different ages. Eur. J. Psychol. Educ. 2005, 20, 209-225. [CrossRef]

26. Wigfield, A.; Eccles, J.S. The development of competence beliefs, expectancies for success, and achievement values from childhood through adolescence. In Development of Achievement Motivation; Wigfield, A., Eccles, J., Eds.; Academic Press: San Diego, CA, USA, 2002; pp. 91-120.

27. García, F.; Martínez, I.; Balluerka, N.; Cruise, E.; García, O.F.; Serra, E. Validation of the Five-Factor Self-Concept Questionnaire AF5 in Brazil: Testing factor structure and measurement invariance across language (Brazilian and Spanish), gender and age. Front. Psychol. 2018, 9, 1-14. [CrossRef]

28. Hustinx, P.W.; Kuyper, H.; van der Werf, M.P.; Dijkstra, P. Achievement motivation revisited: New longitudinal data to demonstrate its predictive power. Educ. Psychol. 2009, 29, 561-582. [CrossRef]

29. Legault, L.; Green-Demers, I.; Pelletier, L. Why Do High School Students Lack Motivation in the Classroom? Toward an Understanding of Academic Amotivation and the Role of Social Support. J. Educ. Psychol. 2006, 98, 567-582. [CrossRef]

30. Ryan, A. The peer group as a context for the development of young adolescent motivation and achievement. Child Dev. 2001, 72, 1135-1150. [CrossRef] [PubMed] 
31. Eurostat: Statistical Office of the European Communities. Early Leavers from Education and Training. Available online: https:/ec.europa.eu/eurostat/statistics-explained/index.php/Early_leavers_ from_education_and_training (accessed on 20 June 2019).

32. Mullis, I.V.S.; Martin, M.O.; Loveless, T. 20 Years of TIMSS: International Trends in Mathematics and Science Achievement, Curriculum, and Instruction; TIMSS and PIRLS International Study Center: Chestnut Hill, MA, USA, 2016.

33. Schraad-Tischler, D.; Schiller, C.; Matthias Heller, S.; Siemer, N. Social Justice Index 2017 Social Inclusion Monitor Europe; Bertelsmann Stiftung: Gütersloh, Germany, 2017.

34. Reynolds, A.; Walberg, H.J. A structural model of science achievement. J. Educ. Psychol. 1991, 83, 97-107. [CrossRef]

35. Rumberger, R. Dropping out of middle school: A multilevel analysis of students and schools. Am. Educ. Res. J. 1995, 32, 583-625. [CrossRef]

36. Holmes, C.T.; Matthews, K.M. The effects of nonpromotion on elementary and junior high school pupils: A meta-analysis. Rev. Educ. Res. 1984, 54, 225-236. [CrossRef]

37. Silberglitt, B.; Jimerson, S.; Burns, M.; Appleton, J. Does the Timing of Grade Retention Make a Difference? Examining the Effects of Early Versus Later Retention. Sch. Psychol. Rev. 2006, 35, 134-141.

38. Yubero, S.; Larrañaga, E.; Serna, C. Escuela y fracaso escolar. Los retos de la exclusión educativa. In Exclusión Social y Diversidad; Amador, L.V., Musitu, G., Eds.; Trillas: Mexico City, Mexico, 2011; pp. 169-191.

39. Yubero, S.; Serna, C.; Larrañaga, E. El fracaso escolar como una forma de exclusión social. In Exclusión: Nuevas Formas y Nuevos Contextos; Yubero, S., Larrañaga, E., Morales, J.F., Eds.; Ediciones de Castilla-La Mancha: Cuenca, Spain, 2009; pp. 157-169.

40. Palardy, G.J.; Rumberger, R.W. Teacher effectiveness in first grade: The importance of background qualifications, attitudes, and instructional practices for student learning. Educ. Eval. Policy Anal. 2008, 30, 111-140. [CrossRef]

41. Rosenthal, R. The Pygmalion effect and its mediating mechanisms. In Improving Academic Achievement. Impact of Psychological Factors on Education; Aronson, J., Ed.; Academic Press: San Diego, CA, USA, 2002; pp. $25-36$.

42. Goodenow, C. Classroom belonging among early adolescent students: Relationships to motivation and achievement. J. Early Adolesc. 1993, 13, 21-43. [CrossRef]

43. McMahon, S.D.; Parnes, A.L.; Keys, C.B.; Viola, J.J. School belonging among low-income urban youth with disabilities: Testing a theoretical model. Psychol. Sch. 2008, 45, 387-401. [CrossRef]

44. Bridgeland, J.M.; Balfanz, R.; Moore, L.A.; Friant, R.S. Raising Their Voices: Engaging Students, Teachers and Parents to Help End the School Dropout Epidemic; Civic Enterprises: Washington, DC, USA, 2010.

45. Schulz, L.L.; Rubel, D.J. A Phenomenology of Alienation in High School: The Experiences of Five Male Non-completers. Prof. Sch. Couns. 2011, 14, 286-298. [CrossRef]

46. Birch, S.; Ladd, G. The teacher-child relationship and children's early school adjustment. J. Sch. Psychol. 1997, 35, 61-79. [CrossRef]

47. Estévez, E.; Murgui, S.; Moreno, D.; Musitu, G. Estilos de comunicación familiar, actitud hacia la autoridad institucional y conducta violenta del adolescente en la escuela. Psicothema 2007, 19, 108-113.

48. Greenman, P.S.; Schneider, B.H.; Tomada, G. Stability and change in patterns of peer rejection. Implications for children's academic performance over the time. Sch. Psychol. Int. 2009, 30, 163-183. [CrossRef]

49. Saeidi, M.; Jabbarpour, N. EFL teachers' socio-affective strategy use in relation to students' academic achievement. Int. J. Acad. Res. 2011, 3, 746-750.

50. Wentzel, K.R. Are effective teachers like good parents? Teaching styles and student adjustment in early adolescence. Child Dev. 2002, 73, 287-301. [CrossRef]

51. Shin, R.; Daly, B.; Vera, E. The Relationships of Peer Norms, Ethnic Identity, and Peer Support to School Engagement in Urban Youth. Prof. Sch. Couns. 2007, 10, 379-388. [CrossRef]

52. Antaramian, S.P.; Huebner, E.S.; Valois, R.F. Adolescent Life Satisfaction. Appl. Psychol. Int. Rev. 2008, 57, 112-126. [CrossRef]

53. Elmore, G.M.; Huebner, E.S. Adolescents' satisfaction with school experiences: Relationships with demographics, attachment relationships, and school engagement behavior. Psychol. Sch. 2010, 47, 525-537. [CrossRef]

54. Oberle, E.; Schonert-Reichl, K.A.; Zumbo, B.D. Life satisfaction in early adolescence: Personal, neighbourhood, school, family, and peer influences. J. Youth Adolesc. 2011, 40, 889-901. [CrossRef] [PubMed] 
55. Baker, J.A.; Dilly, L.J.; Aupperlee, J.L.; Patil, S.A. The development of school satisfaction: Schools as psychologically healthy environments. Sch. Psychol. Q. 2003, 18, 206-221. [CrossRef]

56. Huebner, E.S. Preliminary development and validation of a multidimensional life satisfaction scale for children. Psychol. Assess. 1994, 6, 149-158. [CrossRef]

57. Kiuru, N.; Aunola, K.; Vuori, J.; Nurmi, J.E. The role of peer groups in adolescents' educational expectations and adjustment. J. Youth Adolesc. 2007, 36, 995-1009. [CrossRef]

58. Kaplan, H.B.; Toelle, G.C. The Cycle of Deviant Behavior; Springer: New York, NY, USA, 2006.

59. Pérez, M.C.; Gázquez, J.J.; Mercader, I.; Molero, M.M.; García, M.M. Rendimiento académico y conductas antisociales y delictivas en alumnos de Educación Secundaria Obligatoria. Int. J. Psychol. Psychol. Ther. 2011, 11, 401-412.

60. Copeland, J.; Swift, W. Cannabis use disorder: Epidemiology and management. Int. Rev. Psychiatry 2009, 21, 96-103. [CrossRef]

61. L'Engle, K.L.; Jackson, C. Socialization influences on early adolescents' cognitive susceptibility and transition to early sexual intercourse. J. Res. Adolesc. 2008, 18, 353-378. [CrossRef]

62. Buhs, E.S.; Ladd, G.W.; Herald, S.L. Peer exclusion and victimization: Processes that mediate the relation between peer group rejection and children's classroom engagement and achievement? J. Educ. Psychol. 2006, 98, 1-13. [CrossRef]

63. Serna, C.; Larrañaga, E. La violencia en las relaciones entre iguales como obstáculo para el éxito escolar. In Convivir con la Violencia; Yubero, S., Larrañaga, E., Blanco, A., Eds.; Ediciones de la Universidad de Castilla-La Mancha: Cuenca, Spain, 2007; pp. 225-239.

64. Yubero, S.; Serna, C.; Martínez, I. Fracaso escolar y violencia en la escuela: Factores psicológicos y sociales. In Psicología Social y Problemas Sociales; Romay, J., García Mira, R., Real, J.E., Eds.; Biblioteca Nueva: Madrid, Spain, 2005; pp. 375-382.

65. Galdós, J.S.; Sánchez, I.M. Relationship between cocaine dependence treatment and personal values of openness to change and conservation. Adicciones 2010, 22, 51-58. [CrossRef]

66. Saiz, J.; Álvaro, J.L.; Martínez, I. Relation between personality traits and personal values in cocaine-dependent patients. Adicciones 2011, 23, 125-132. [CrossRef]

67. Eisenberg, N.; Fabes, R.A.; Spinrad, T.L. Prosocial development. In Handbook of Child Psychology; Damon, W., Eisenberg, N., Eds.; John Wiley \& Sons: New York, NY, USA, 2006; Volume 3: Social, emotional and personality development, pp. 646-718.

68. Gilman, R.; Anderman, E.M. The relationship between relative levels of motivation and intrapersonal, interpersonal, and academic functioning among older adolescents. J. Sch. Psychol. 2006, 44, 375-391. [CrossRef]

69. Inglés, C.J.; Delgado, B.; García-Fernández, J.M.; Ruiz-Esteban, C.; Díaz-Herrero, A. Sociometric types and social interaction styles in a sample of Spanish adolescents. Span. J. Psychol. 2010, 13, 728-738. [CrossRef] [PubMed]

70. Garaigordobil, M. A comparative analysis of empathy in childhood and adolescence: Gender differences and associated socio-emotional variables. Int. J. Psychol. Psychol. Ther. 2009, 9, 217-235.

71. Inglés, C.J.; Martínez, A.E.; Valle, A.; García-Fernández, J.M.; Ruiz-Esteban, C. Conducta prosocial y motivación académica en estudiantes españoles de Educación Secundaria Obligatoria. Univ. Psychol. 2011, 10, 557-571. [CrossRef]

72. Inglés, C.J.; Martínez-González, A.E.; García-Fernández, J.M. Conducta prosocial y estrategias de aprendizaje en una muestra de estudiantes españoles de Educación Secundaria Obligatoria. Eur. J. Educ. Psychol. 2013, 6, 33-53. [CrossRef]

73. Pakaslahti, L.; Karjalainen, A.; Keltikangas-Järvinen, L. Relationships between adolescent prosocial problemsolving strategies, prosocial behaviour, and social acceptance. Int. J. Behevioral Dev. 2002, 26, 137-144. [CrossRef]

74. Eisenberg, N.; Fabes, R.A. Prosocial development. In Handbook of Child Psychology: Social, Emotinal and Personality Development; Damon, W., Eisenberg, N., Eds.; Wiley: New York, NY, USA, 1998; pp. 701-778.

75. Inglés, C.J.; Hidalgo, M.D.; Méndez, F.X.; Inderbitzen, H.M. The Teenage Inventory of Social Skills: Reliability and validity of the Spanish translation. J. Adolesc. 2003, 26, 505-510. [CrossRef]

76. Díaz-Aguado, M.J.; Martín, G. Convivencia y aprendizaje escolar en la adolescencia desde una perspectiva de género. Psicothema 2011, 23, 252-259. 
77. Fernández-Lasarte, O.; Goñi, E.; Camino, I.; Zubeldia, M. School Adjustment and Academic Self-Concept in Secondary Education. Rev. Investig. Educ. 2019, 37, 163-179.

78. Logan, S.; Johnston, R. Gender differences in reading ability and attitudes: Examining where these differences lie. J. Res. Read. 2009, 32, 199-214. [CrossRef]

79. Rothon, C.; Arephin, M.; Klineberg, E.; Cattell, V.; Stansfeld, S. Structural and socio-psychological influences on adolescents' educational aspirations and subsequent academic achievement. Soc. Psychol. Educ. 2011, 14, 209-231. [CrossRef] [PubMed]

80. Antonio-Agirre, I.; Azpiazu, L.; Esnaola, I.; Sarasa, M. Capacidad predictiva del autoconcepto y la inteligencia emocional en el ajuste escolar autopercibido. Bordón. Rev. Pedagog. 2015, 67, 9-26. [CrossRef]

81. Ibabe, I. Academic failure and child-to-parent violence: Family protective factors. Front. Psychol. 2016, 7, 1-11. [CrossRef] [PubMed]

82. Kalton, G. Introduction to Survey Sampling; Sage: Beverly Hills, CA, USA, 1983. [CrossRef]

83. Manz, P.; Fantuzzo, J.; Power, T. Multidimensional assessment of family involvement among urban elementary students. J. Sch. Psychol. 2004, 42, 461-475. [CrossRef]

84. Anderson, K.; Minke, K. Parent Involvement in Education: Toward an Understanding of Parents' Decision Making. J. Educ. Res. 2007, 100, 311-323. [CrossRef]

85. Marti, D. A multidimensional look at immigrant Latin American immigrant family involvement in education. Diss. Abstr. Int. Sect. A Humanit. Soc. Sci. 2009, 70, 95.

86. McWayne, C.; Campos, R.; Owsianik, M. A multidimensional, multilevel examination of mother and father involvement among culturally diverse Head Start families. J. Sch. Psychol. 2008, 46, 551-573. [CrossRef]

87. Cheung, H.Y.; Hui, S.K.F. Mainland immigrant and Hong Kong local students' psychological sense of school membership. Asian Pac. Educ. Rev. 2003, 4, 67-74. [CrossRef]

88. Roche, C. Making the Grade: Academic Achievement among Latino Adolescents. Ph.D. Thesis, Georgia State University, Atlanta, GA, USA, 2005.

89. Nelson, R.M.; DeBacker, T.K. Achievement motivation in adolescents: The role of peer climate and best friends. J. Exp. Educ. 2008, 76, 170-189. [CrossRef]

90. Sánchez, B.; Colon, Y.; Esparza, P. The role of sense of school belonging and gender in the academic adjustment of Latino adolescents. J. Youth Adolesc. 2005, 34, 619-628. [CrossRef]

91. Walker, C.O.; Greene, B.A. The relations between student motivational beliefs and cognitive engagement in high school. J. Educ. Res. 2009, 102, 463-471. [CrossRef]

92. Huebner, E.S.; Gilman, R. An introduction to the Multidimensional Students' Life Satisfaction Scale. Soc. Indic. Res. 2002, 60, 115-122. [CrossRef]

93. Huebner, E.S.; Laughlin, J.; Ash, C.; Gilman, R. Further validation of the Multidimensional Students' Life Satisfaction Scale. J. Psychol. Assess. 1998, 16, 118-134. [CrossRef]

94. Gilman, R.; Huebner, E.S.; Laughlin, J. A first study of the Multidimensional Students' Life Scale with adolescents. Soc. Indic. Res. 2000, 52, 135-160. [CrossRef]

95. Gilman, R.; Huebner, E.S.; Tian, L.; Park, N.; O’Byrne, J.; Schiff, M.; Sverko, D.; Langknecht, H. Cross-national adolescent multidimensional life satisfaction reports: Analyses of mean scores and response style differences. J. Youth Adolesc. 2008, 37, 142-154. [CrossRef]

96. Huebner, E.S.; Suldo, S.; Gilman, R. Life Satisfaction. In Children's Needs III: Development, Prevention and Intervention; Bear, G.G., Minke, K.M., Eds.; National Association of School Psychologists: Washington, DC, USA, 2006; pp. 357-368.

97. Inderbitzen, H.M.; Foster, S.L. The Teenage Inventory of Social Skills: Development, reliability, and validity. Psychol. Assess. 1992, 4, 451-459. [CrossRef]

98. Dishion, T.J. The family ecology of boys' peer relations in middle childhood. Child Dev. 1990, 61, 874-892. [CrossRef]

99. Parra, A. Familia y Desarrollo Adolescente: Un Estudio Longitudinal Sobre Trayectorias Evolutivas. Ph.D. Thesis, Universidad de Sevilla, Sevilla, Spain, 2005.

100. Martínez, I.; Fuentes, M.C.; García, F.; Madrid, I. The parenting style as protective or risk factor for substance use and other behavior problems among Spanish adolescents. Adicciones 2013, 25, 235-242. [CrossRef]

101. Gilman, R.; Huebner, E.S. Characteristics of adolescents who report very high life satisfaction. J. Youth Adolesc. 2006, 35, 293-301. [CrossRef] 
102. Martínez, I.; Cruise, E.; García, O.F.; Murgui, S. English validation of the Parental Socialization Scale-ESPA29. Front. Psychol. 2017, 8, 1-10. [CrossRef]

103. Martínez, I.; García, F.; Fuentes, M.C.; Veiga, F.; García, O.F.; Rodrigues, Y.; Cruise, E.; Serra, E. Researching parental socialization styles across three cultural contexts: Scale ESPA29 bi-dimensional validity in Spain, Portugal, and Brazil. Int. J. Environ. Res. Public Health 2019, 16, 197. [CrossRef]

104. Martínez, I.; García, J.F. Impact of parenting styles on adolescents' self-esteem and internalization of values in Spain. Span. J. Psychol. 2007, 10, 338-348. [CrossRef]

105. Martínez, I.; García, J.F. Internalization of values and self-esteem among Brazilian teenagers from authoritative, indulgent, authoritarian, and neglectful homes. Adolescence 2008, 43, 13-29.

106. Buelga, S.; Musitu, G.; Murgui, S. Relaciones entre la reputación social y la agresión relacional en la adolescencia. Int. J. Clin. Health Psychol. 2009, 9, 127-141.

107. Méndez, I.; Cerezo, F. La repetición escolar en educación secundaria y factores de riesgo asociados. Educ. XX1 2018, 21, 41-62. [CrossRef]

108. Smyth, J. When students have power: Student engagement, student voice, and the possibilities for school reform around' dropping out of school. Int. J. Leadersh. Educ. 2009, 9, 285-298. [CrossRef]

109. Inglés, C.J.; Benavides, G.; Redondo, J.; García-Fernández, J.M.; Ruiz-Esteban, C.; Estévez, C.; Huescar, E. Conducta prosocial y rendimiento académico en estudiantes españoles de Educación Secundaria Obligatoria. An. Psicol. 2009, 25, 93-101.

110. Wentzel, K.R. Sociometric status and adjustment in middle school: A longitudinal study. J. Early Adolesc. 2003, 23, 5-28. [CrossRef]

111. Wentzel, K.R. Peer relationships, motivation, and academic performance at school. In Handbook of Competence and Motivation; Elliot, A.J., Dweck, C.S., Eds.; Guilford Press: New York, NY, USA, 2005; pp. 279-296.

112. Martínez, I.; García, J.F.; Camino, L.; Camino, C.P.S. Parental socialization: Brazilian adaptation of the ESPA29 scale. Psicol. Reflexão E Crítica 2011, 24, 640-647. [CrossRef]

113. Atienza, F.L.; Balaguer, I.; García-Merita, M.L. Satisfaction with life scale: Analysis of factorial invariance across sexes. Personal. Individ. Differ. 2003, 35, 1255-1260. [CrossRef]

114. Castillo, I.; Balaguer, I.; Duda, J.L. Las teorías personales sobre el logro académico y su relación con la alienación escolar. Psicothema 2003, 15, 75-81.

115. Casas, F.; Sarriera, J.C.; Alfaro, J.; González, M.; Figuer, C.; Abs da Cruz, D.; Bedin, L.; Valdenegro, B.; Oyarzún, D. Satisfacción escolar y bienestar subjetivo en la adolescencia: Poniendo a prueba indicadores para su medición comparativa en Brasil, Chile y España. Suma Psicológica 2014, 21, 70-80. [CrossRef]

116. Tomyn, A.J.; Cummins, R.A. The subjective wellbeing of high-school students: Validating the Personal Wellbeing Index-School Children. Soc. Indic. Res. 2011, 101, 405-418. [CrossRef] 